\title{
横桁による並列主桁の横補剛効果

\author{
LATERAL BUCKLING STRENGTH AND BRACING \\ EFFECT OF CROSS BEAMS
}

\author{
西田進*.吉田博**.福本唀士*** \\ By Susumu NISHIDA, Hiroshi YOSHIDA and Yuhshi FUKUMOTO
}

\section{1. 緒言}

橋梁などにおいて, 主析に対する横桁, 横構, 対傾構 の補剛効果の検討は橋梁全体の横方向一の安全性を確保 するらえで重要な問題である.

本研究は荷重分配桁として用いられる横桁のもつ並列 主桁への横補剛効果の検討を行うものである.

横補剛効果に関するこれまでの研究は，(1) 塑性設計 ばり，(2) はりの横倒れ座屈, および (3) 並列桁に関 する研究, に大別できる.

（1） はりの塑性設計の分野において, 塑性モーメン トと所要の塑性回転能を確保寸るために, 数多くの補剛 効果に関する研究が行われてきた. その代表的研究とし て, 上下フランジの水平変位を完全に拘束したはりの実 験的研究 ${ }^{1) \sim 4)}$, 初期変形が存在し, 横拘束ばねを有する はりに関する理論的研究5), および板ばねを用いて補剛 する力を実験的に求めた研究22) がある.

特に, 鈴木, 小野 ${ }^{1)}$ は補剛点の横方向移動を完全に拘 束した状態で, 塑性設計ばりの補剛間隔と回転容量およ び隣接スパンの影響を中心に，等曲げを受ける場合，モ 一メント勾配を有する場合, および塑性ヒンジ発生点を 拘束する場合について実験を行った. また, 彼らは横座 屈後の挙動の検討も行い, 実験值と Lay の式5) がよく 一致することを示した.

最相, 田中 ${ }^{6)}$ は初期変形を有し, 横拘束ばねのあるは りの塑性流れ, ひずみ硬化, および除荷時の荷重・変形 量の関倸を有限要素法増分解より求め, その結果を用い て横補剛点に作用する力の大きさを求めている.

これらの研究により, 塑性設計ばりの 横補剛力とし て, 圧縮フランジ降伏軸力の $2 \%$ 程度を確保すれば所

* 正会員 工修 金沢工業大学講師 土木工学科

** 正会員 工博 金沢大学助教授 工学部土木工学科

*** 正会員 $\mathrm{Ph}$. D., 工博 名古屋大学教授 工学部土木工学 科
要の塑性回転容量が得られることがわかった。

（2）横倒れ座屈強度に及ぼす横補剛効果の影響に関 する研究としては, 載荷点に横拘束ばねを有するはりに 関する研究 ${ }^{7,8)}$, 分布ば站を有するはり関する研究 ${ }^{7)}$, はりの初期変形を考虑し, 載荷点での横拘束ばねによる 水平反力と座屈強度の関係を求めた研究 ${ }^{9), 10)}$ がある.

特に, Hartman ${ }^{11)}$ は差分法を用いて, 集中荷重を受 ける単純ばり，2 スパンおよび 3 スパン連続ばりの弾性 座屈解析を行い, 支点および載荷点での横拘束ばね定数 (あるいはねじれ拘束ばね定数) と強度の関倸を求めて いる. その解析結果より, 単純ばりでは横拘束ばねの効 果が大きく, 連続ばりでは横拘束より, 中間支承のねじ れ拘束の方が効果的だと報告している.

(3) 曲げによる並列妳の横倒れ座屈強度の研究とし ては, 屋根ばりを対象に並列析のフランジに波板を取り つけた構造系に関する研究 ${ }^{12), 13)}$, 横桁によるねじれ拘 束を等価な分布ねじれ拘束ばねにおきかえて, 各種の載 荷状態に扔ける座屈強度を求めた研究 ${ }^{14}$ がある.

福本, 久保 $\left.{ }^{15)}, 16\right)$ は横構, 対傾構を有寸る並列析の等 曲げによる横倒れ座屈強度を Rayleigh-Ritz 法を用い て理論解析を行った．また，理論解析とともに，200× $100 \times 5.5 \times 8 \mathrm{~mm}$ の $\mathrm{H}$ 形断面並列ばりに, 横構の各種組 合せ, 横構とはり中央に対傾構を用いた場合の横倒れ座 屈実験を行い, 有効座屈長さの検討を行っている.

おもに，塑性設計ばりで研究されてきた水平補剛（た だし，主桁間を横桁などで補剛する場合）は並列桁全体 の同一横方向への変形を直接拘束することができない. 福本, 久保 ${ }^{15)}$ は中間対傾構のみでは横補剛点で, 並列桁 の面外変位拘束はできなく, 並列桁のねじれ変形を拘束 することによって座屈強度は向上されると報告してい る.

曲げによる桁の圧縮フランジの応力が析の横倒れ座屈 により決まる場合, 橋梁の設計では, 固定点間距離を横 倒れ座屈長さにとっている. この場合, 固定点としての 
機能を十分に発揮するには，i）横補剛点において，断 面の水平変位およびねじり角が零となるように完全に拘 束する, ii）横補剛点に招いて, 断面の水平変位は完全 に拘束されなくても，㸚じり角を拘束することにより， 座屈強度を，拘束点間距離を横倒れ座屈長さとした場合 の強度より向上せしめることができることが必要であ る.

本論文では，横桁によって横補剛された並列桁の横倒 れ座屈強度について理論解を求め, 桁の圧縮フランジの 曲げ応力の照查に用いられる固定点間距離の概念につい て検討を加え，並列析全体として設計抵抗モーメントを 安全に維持するための補剛条件を満足させるに必要な横 桁の必要剛度と，並列桁を補剛する位置について検討す る.

なお，通常の道路橋と異なり，歩道橋のようにスパン 長/幅員が極端に大きくなる場合には, 横桁が拘束材と して作用する並列桁の個々の桁の座屈のみでなく，並列 桁全体として横倒れ座屈する場合がある.ここでは, 並 列主析間の横補剛材として対傾構，上・下横構を配置す ることなく，横桁のみを配置した場合の横桁による主桁 の圧縮フランジの横座屈に対する拘束の影響を明らかに しょうとするものであり, 極端な構造寸法がもつ全体座 屈は検討の対象外とした。

\section{2. 理 論解析}

\section{解析に用いた仮定}

（1）並列桁は等断面 I 形を有する 2 主桁からなり， 横倒れ座屈に対して初期変形はない。 また, 座屈時の断 面の変形 (distorsion) は考えない.

（2）横桁は 2 軸対称断面とし, 主桁の座屈に際して 弾性挙動する.

（3）主析の鋼材は完全弾塑性体である.

（4）主桁の残留応力分布としてはりタイプの場合は 圧延成形によるものを，桁タイプの場合は溶接組立によ るものを理想化した Fig. 1 に示すような残留応力分布 を用いる。

（5）両主桁の断面寸法は等しく，かつ横変位および ねじれに対して両端単純支持とし, 横桁は主桁の軸方向 とウェブ面に対して直角に取り付ける.

（6）並列桁には同一荷重が作用し，並列 2 主桁の横 変位 $u$ およびねじれ角 $\varphi$ は Fig. 2 に示すように同符 号で等しいか, 逆符号で等しい。

（7）ここでは，Fig. 2 に示すように並列析の個々 の桁が水平変形とともに，それぞれの断面のねじり中心 まわりにねじれる座屈モードを研究の対象とする．すな わち, このような座屈モードは, 並列桁一体としての水

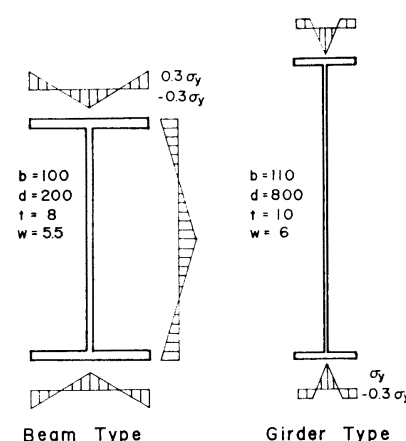

Fig. 1 Idealized Residual Stress Distributions

平方向の曲げ剛度が鉛直 方向の曲げ剛度に比して かなり大きく確保されて いる場合であり，このよ うな場合には，並列桁の 断面全体としての㸚じれ 変形を伴う座屈モード, いわゆる全体座屈が生ず ることはない．

横桁によって連結され た並列 2 主桁が Fig. 3 に示すように等曲げを受 ける場合 (ケース A), 等分布荷重満載の場合 (ケース B)，およびスパ ン中心に集中荷重を受け る場合 (ケースC) の 3 種の載荷状態についての 横倒れ座屈解析を伝達マ トリックス法を用いて行

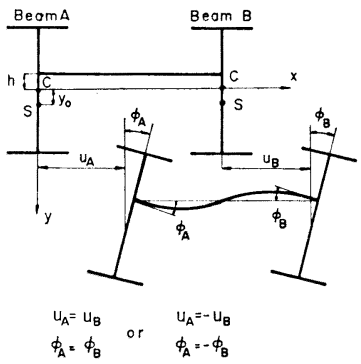

Fig. 2 Buckled Deformation of a Parallel Beam

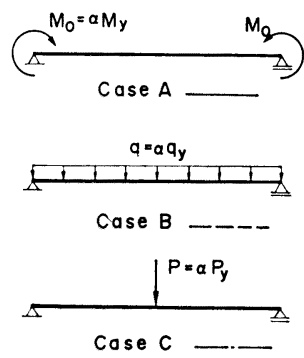

Fig. 3 Loading Conditions 5 .

伝達マトリックス法を用いたはりの弾性および非弹性 横倒れ座屈解析は 文献 17) に詳細に 述べられているの で，ここでは横桁位置での格点伝達マトリックスについ てのみ説明を行う.

個々の桁が単独に座屈変形しようとするのを中間に設 けた横桁により変形拘束を行っておりり，上記の (6)，(7) の仮定を用いれば，横桁は拘束ばねとして扱らことがで き, 並列桁の片側主桁についてのみ解析を行えばよい. はり要素の変形量および荷重項の正方向を Fig. 4 のよ うにとり，横桁の影響を拘束ば㸚として扱らと，トラス 理論およびたわみ角法より，横変位拘束ばね定数 $K_{A}$, ねじれ拘束ばね定数 $K_{x}$ ，および横たわみ角拘束ばね定 数 $K_{y}$ は次のようになる.

同一モードで変形する場合 


$$
K_{A}=0, K_{x}=6 \frac{E I_{x c}}{L_{c}}, K_{y}=6 \frac{E I_{y c}}{L_{c}}
$$

逆モードで変形する場合

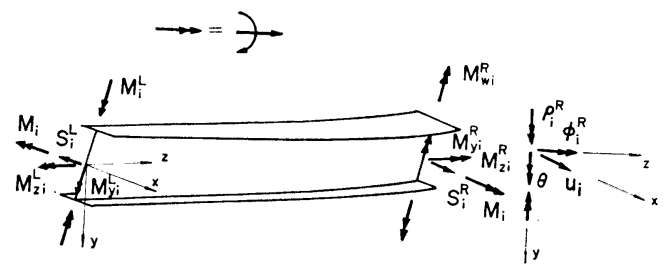

Fig. 4 Positive Directions of State Vector

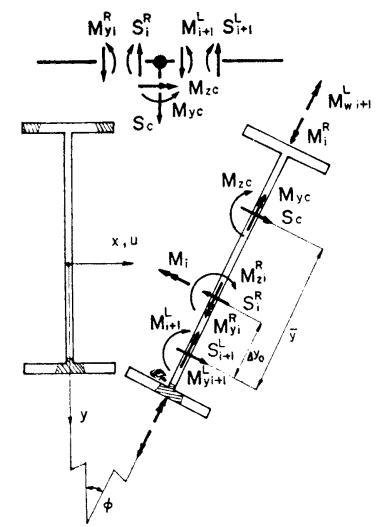

Fig. 5 Forces at the Point Connected with a Cross Beam

$$
K_{A}=2 \frac{E A_{c}}{L_{c}}, K_{x}=2 \frac{E I_{x c}}{L_{c}}, K_{y}=2 \frac{E I_{y c}}{L_{c}} \cdots
$$

ここに, $A_{c}$ : 横析断面積, $I_{x c}$ および $I_{y c}$ : 横桁の強軸 および弱軸まわりの断面 2 次モーメント, $L_{c}$ : 横桁の 部材長さである.

したがって，横桁によって連結される $i$ 番目要素右 端と, $i+1$ 番目要素左端の 連続条件は Fig. 5 と文献 18)より,

$$
\begin{aligned}
& u_{i+1}^{L}=u_{i}{ }^{R}-\Delta y_{0} \varphi_{i}{ }^{R} \quad \varphi_{i+1}^{L}=\varphi_{i}{ }^{R} \\
& \theta_{i+1}^{L}=\theta_{i}{ }^{R}-\Delta y_{0} \rho_{i}{ }^{R} \quad \rho_{i+1}^{L}=\rho_{i}{ }^{R} \\
& S_{i+1}^{L}=S_{i}{ }^{R}-S_{c} \quad M_{y i+1}^{L}=M_{y i}{ }^{R}-M_{y c} \\
& M_{z i+1}^{L}=M_{z i}{ }^{R}+\Delta y_{0} S_{i}{ }^{R}-M_{i} \Delta y_{0} \rho_{i}{ }^{R} \\
& -M_{z c}-S_{c} \bar{y} \\
& M_{\omega i+1}^{L}=M_{\omega i}{ }^{R}+\Delta y_{0} M_{y i}{ }^{R}-M_{y c} \bar{y}
\end{aligned}
$$

18）となる.ここに, $u, \theta, \varphi$ および $\rho:$ 主桁の横変位, 横たわみ角, ねじれ角, およびねじれ率, $S, M_{y}, M_{z}$ お よび $M_{\omega}$ : 横方向せん断力, 横方向曲げモーメント, ね じれモーメント，拉よびバイ・モーメントである。 ま た, $\Delta y_{0}: i$ 番目要素と $i+1$ 番目要素のせん断中心間距 離, $\bar{y}:$ 横枌のせん断中心（重心と一致する）と $i+1$ 番目要素のせん断中心との距離である. $S_{c}, M_{y c}$ ，およ び $M_{z c}$ : 横桁（各拘束ばね）による各反力, $M_{i}: i$ 番 目要素の面内曲げモーメントである.

上記連続条件をマトリックス表示すると，以下に示す 格間伝達マトリックスが得られる.

$\left\{\begin{array}{c}u \\ \theta \\ \varphi \\ \rho \\ M_{y} \\ M_{z} \\ M_{\omega}\end{array}\right\}_{i+1}^{L}\left[\begin{array}{cccccccc}1 & 0 & -\Delta y_{0} & 0 & 0 & 0 & 0 & 0 \\ 0 & 1 & 0 & -\Delta y_{0} & 0 & 0 & 0 & 0 \\ 0 & 0 & 1 & 0 & 0 & 0 & 0 & 0 \\ 0 & 0 & 0 & 1 & 0 & 0 & 0 & 0 \\ K_{A} & 0 & K_{A} \bar{y} & 0 & 1 & 0 & 0 & 0 \\ 0 & -K_{y} & 0 & -K_{y} \bar{y} & 0 & 1 & 0 & 0 \\ K_{A} \Delta y_{0} & 0 & K_{x}+K_{A} \Delta y_{0} \bar{y} & -M_{i} \Delta y_{0} & \Delta y_{0} & 0 & 1 & 0 \\ 0 & -K_{i} \Delta y_{0} & 0 & -K_{y} \Delta y_{0} \bar{y} & 0 & \Delta y_{0} & 0 & 1\end{array}\right]\left\{\begin{array}{c}u \\ \theta \\ \varphi \\ \rho \\ S \\ M_{y} \\ M_{z} \\ M_{\omega}\end{array}\right\}_{i}$

ここに, $K_{A}, K_{y}$ および $K_{x}$ : 横変位拘束ばね定数, 横 一メント, $L:$ 並列桁のスパン長である.

たわみ角拘束ばね定数およびねじれ角拘束ばね定数であ る.なお，数值計算は式 (1) の同一モードと式 (2)の 逆モードの両方の拘束ばね定数に対して行い, 座屈荷重 の值は両方から得られる值の小さい方を採用する.

数值計算における横桁剛度を表わすパラメーターとし て, 横桁の断面積 $A_{c}$ と主桁の圧縮フランジ断面積 $b_{t}$ との比を $\delta$, 横桁の強軸および弱軸まわりの断面 2 次モ 一メント $I_{x c}, I_{y c}$ と主桁の圧縮フランジのフランジ面 内に関する断面 2 次モーメント $t b^{3} / 12$ との比を $r_{x}$ お よび $r_{y}$ とする. また, 各載荷条件に対する座屈荷重を ケース $A$ については $M_{y}$, ケース $B$ については $q_{y}=$ $8 M_{y} / L^{2}$, ケース $C$ については $P_{y}=4 M_{y} / L$ で無次元 表示した係数 $\alpha$ を用いる. ここに $M_{y}$ : 主桁の降伏モ

\section{3. 数值計算例および考察}

\section{（1）横桁のもつ各種剛比值と横補剛効果との関係}

数值計算はすべて, Fig. 1 に示すような $\mathrm{H}-200 \times$ $100 \times 5.5 \times 8 \mathrm{~mm}$ のはりタイプの断面注）と I- $800 \times 110$ $\times 6 \times 10 \mathrm{~mm}$ の桁タイプの断面注)を有する両端単純支持 ばりについて行う．両端での座屈変形に対する境界条件

注）はり断面として圧延H形鋼断面を，桁断面としてプレー ト・ガーダー断面を指しており，ここでは並列ばりの横倒

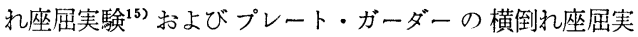
験 ${ }^{19}$ に用いられた断面寸法を用いた数值計算例を示す。 
は横たわみおよびねじれに対して単純支持, そりに対し て自由である.計算に用いた鋼材の降伏応力は $\sigma_{y}=$ $2400 \mathrm{~kg} / \mathrm{cm}^{2}$, ポアソン比は $\nu=0.3$ である.

横桁に上る横補剛効果は細長比, 残留応力分布, 主桁 断面形状および載荷条件によって異なると思われるの でまず細長比 $L / r_{y}=400$ を用いて，比較的細長い主 桁を対象に横析の各剛比パラメーターの影響の検討を行 う. また, 横桁長さ $L_{c}$ は主桁の弱軸まわりの断面 2 次 半径 $r_{y}$ の 40 倍とした. したがって, ほかの横析長さ の場合は式 (1) および (2) からもわかるように, 以下 の図に示す $\delta$ および $r$ の值を $40 r_{y} / L_{c}$ 倍した值とな る.

Fig. 6 は座屈強度に及ぼす横析断面積の影響を調べ たものである. 図の右は主桁のスパン中央に横桁が 1 本 ある場合の $\delta=0$ および $\delta=\infty に$ 対して, 横桁の剛比 $r_{x}$ のみを変化させた場合の座屈強度 $\alpha$ の大きさを, 3 種の載荷条件に対して求めたものである. 左側の図は $\delta=0$ と $\delta=\infty$ のときの $\alpha$ 值の開きが大きく表われて いる $r_{x}=0.01$ について, $\delta$ のみ変化させた場合の $\alpha$ の大きさを求めたものである. 図の左下に，等曲げが 作用するはりの座屈モードを示す. 図より, いずれの載 荷方法においても横桁の必要断面積, 換言すれば図中の 座屈モードが変わる $\delta=1 \times 10^{-4}$ 近傍より大きな $\delta$ に対 して並列 2 主桁は拘束点で同一方向一座屈するか, ある いは横変位が零となることがわかる．桁タイプの断面に ついても同様の結果が得られた.一般に用いられる横桁 断面積は $\delta=1 \times 10^{-4}$ よりかなり大きく，したがって， 以下の計算では $\delta=1.0$ を用い, 横桁の必要断面積は十 分に確保されているとした.

Fig. 7 および 8 は横桁の曲げ岡比 $r_{x}$ および $r_{y}$ の 影響を検討するために, 並列桁の両端から $L / 3$ 点に横 桁を 2 本配置した場合のはりタイプおよび桁タイプの並 列桁の座屈強度の大きさを示す. 横軸には $r_{y}=0$ とした ときの $r_{x}, r_{x}=0$ としたときの $r_{y}$, および $r_{x}=10 r_{y}$ （桁タイプでは $r_{x}=200 r_{y}$ ）としたときについて示す.

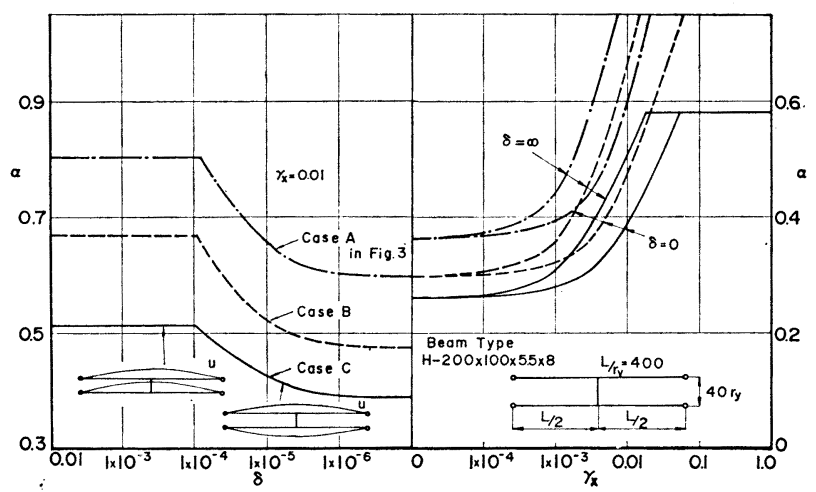

Fig. 6 Effect of $\delta$ on the Lateral Buckling (Beam Type)

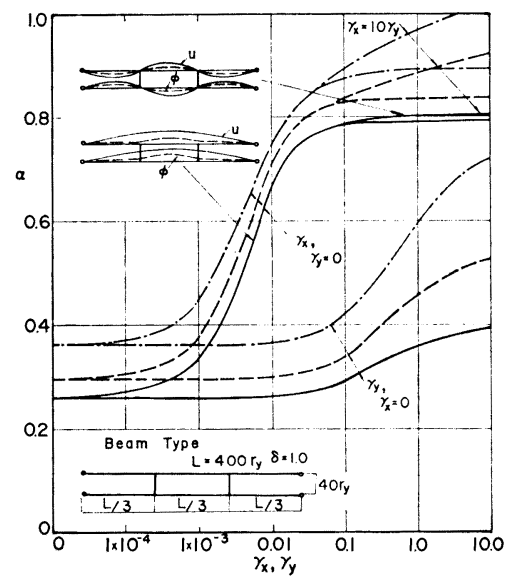

Fig. 7 Effect of $r$ on the Lateral Buckling (Beam Type)

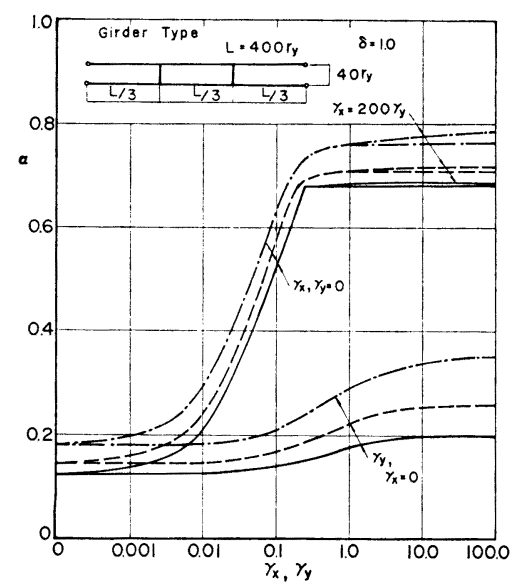

Fig. 8 Effect of $\gamma$ on the Lateral Buckling (Girder Type)

はりタイプの主桁の強軸と弱軸まわりの断面 2 次モーメ ントの比が約 10 なので $r_{x}$ と $\gamma_{y}$ の比として $\gamma_{x}=10$ $r_{y}$ を用いた. 桁タイプの断面についても同様の理由で $r_{x}=200 r_{y}$ を用いた.

図より，横析の弱軸まわりの剛性 $\left(r_{\boldsymbol{y}}\right)$ の影響 は強軸まわりの剛性 $\left(r_{x}\right)$ の影響に比べて小さ く, 特に桁タイプではほとんど無視できる程度で ある、また，図中のモードは等曲げを受けるはり の座屈モードの変化を示す.なお, 桁のスパン中 央に横桁 1 本を配置した場合には, 並列析は同一 方向に横座屈し, 中央部における横変位の勾配は 零となるので, $r_{x}=0$ としたときの $r_{y}$ による影 響は表われない。

Fig. 9 は $r_{x}=10, r_{y}=0$ と $r_{x}=10, r_{y}=1$ の 横桁を有するはりタイプの断面について，横桁位 置を材端からスパン中央へ変化させた場合の座屈 


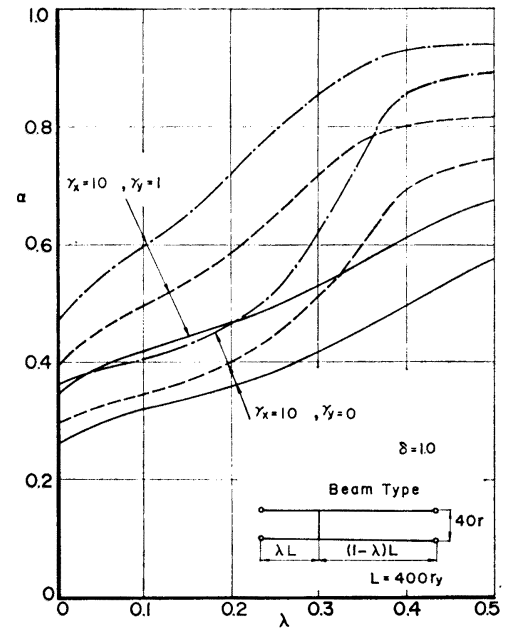

Fig. 9 Effect of Braced Locations on the Lateral Buckling (Beam Type)

強度の大きさを示す．横析がスパン中央にある場合に強 度は最も大きく, 特に載荷点を横桁により拘束すること になるケース Cの補剛効果は大きく表われる. しかし， $r_{x}=10, r_{y}=0$ と $r_{x}=10, r_{y}=1$ の強度差は横桁位置に 関係なく，ほぼ同程度となっている. Fig. 8 と同様, 桁タイプでは，はりタイプの場合と異なり， $r_{y}$ による 補剛効果はあまり期待できないことが明らかになった.

Fig. 6〜9 より横桁の主桁に対する横補剛効果として は, 主桁のねじれを拘束する横桁の強軸まわりの断面 2 次モーメントの影響が最も大きい. 両主桁の横変位差を 拘束する横桁断面積はきわめて小さな值で十分であり, 横桁の強軸まわりの剛度が大きいときには弱軸まわりの 剛度に対して, 補剛効果が期待できる. 横桁による横補 剛効果は, $\delta, r_{x}$ および $r_{y}$ の増加に対して, 各載荷条 件ともほぼ一様の座屈強度の上昇をみることができる.

\section{（2）横補剛効果と拘束点間座屈の関係}

横枌 は通常，並列桁に対してほぼ 等間隔に配置され る. 横桁の剛度は弱軸（面外）まわりの方が強軸（面内） まわりに比してかなり小さく，また，Fig. 7 および 8 より $r_{y}$ の影響を無視しても座屈強度の評価は安全側に なる.したがって,ここでは等間隔に配置され，強軸ま わりの剛性（ねじれ拘束ばね定数 $K_{x}$ ）のみを有する横 桁の等分布荷重が作用する並列桁に対する横補剛効果の 検討を行う。また, 横補剛効果に及ぼす断面形状および 残留応力分布の影響も検討するために，断面形状につい ては断面のフランジ幅/桁高さ $(b / d)$ の異なる H-600 $\times 200 \times 11 \times 17 \mathrm{~mm}, \mathrm{I}-3820 \times 762 \times 22 \times 40 \mathrm{~mm}, \mathrm{I}-800 \times$ $110 \times 6 \times 10 \mathrm{~mm}$ の 3 種の断面を用い, 一方, 残留応力 分布としては Fig. 1 の溶接組立による直線タイプとフ

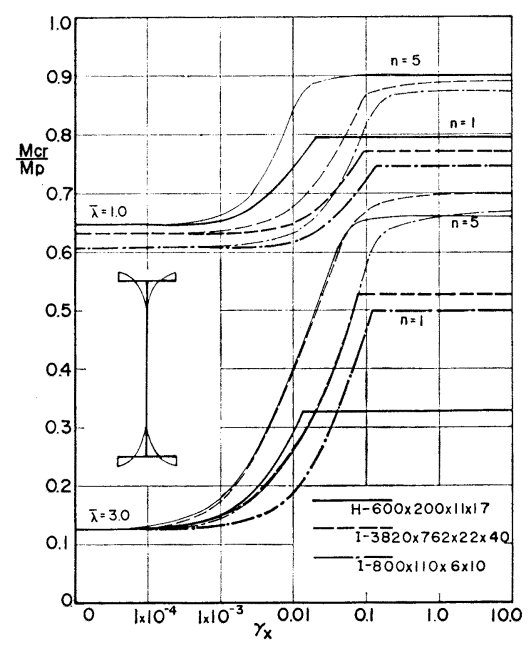

Fig. 10 Relationship Between $\gamma_{t}$ versus Lateral Buckling Strength

ランジ内でつり合う放物線タイプ（式 (5) および Fig. 10 参照) の 2 通りの残留応力分布形状を用いた.

$$
\sigma_{r}=\sigma_{r t}+\left(\sigma_{r c}-\sigma_{r t}\right)\left\{\frac{2|x|}{b}\right\}^{-\sigma_{r c} / \sigma_{r t}}
$$

ここに, $|x|$ は Fig. 5 に示す $x$ 座標の絶対值を表わ す.

Fig. 10 は放物線タイプの残留応力を有する並列桁の 座屈強度と $r_{x}$ の関係を示す. 座屈強度は $M_{c r} / M_{p}$ を 縦軸に, $r_{\boldsymbol{x}}$ を横軸にとり， $\bar{\lambda}=1.0$ と 3.0 の並列析長 について示す. ここに, $M_{c r}$ : 座屈等分布荷重によるス パン中央の曲げモーメント $q_{c r} L^{2} / 8, M_{p}$ : 全塑性モーメ ント, $\bar{\lambda}=\sqrt{M_{p} / M_{E}}$ を表わす. $M_{E}$ は単純支持された 一本の桁が等曲げモーメントを受けるときの弾性座屈モ ーメントを示す.

$$
M_{E}{ }^{2}=\frac{\pi^{2} E I_{y}}{L^{2}} G K_{T}+\frac{\pi^{2} E I_{\omega}}{L^{2}}
$$

ここに, $E I_{y}: y$ 軸まわりの曲げ剛性, $G K_{T}: \mathrm{St} . \mathrm{Ve}$ nant のねじり剛性, $E I_{\omega}$ : そり剛性を示す。

図中, 太線は横桁 1 本 $(n=1)$ 有する場合を, 細線は 横桁 5 本 $(n=5)$ 有する場合を示す. 図のような表示を すると, ねじれ拘束を有する並列桁の座屈強度は断面寸 法および横桁本数によって大きく異なる.この断面寸法 および横析本数の影響を打ち消すような 表示をするた め, 次に示す基準ねじれ拘束ばね定数 $K_{1}$ および基準座 屈モーメント $\bar{M}_{c r}$ を導入する.

スパン中央にねじれ拘束ばねを有する単純ばりに等曲 げが作用した場合，はりは 2 次のモード

$$
u=A \sin \frac{2 \pi z}{L}, \varphi=B \sin \frac{2 \pi z}{L}
$$

で座屈するか，あるいは式（7）で近似されるような， ねじれのみが拘束されるモードで座屈する. 


$$
u=A \sin \frac{\pi}{L} z, \varphi=B_{1} \sin \frac{\pi}{L} z+B_{1} \sin \frac{3 \pi}{L} z
$$

式 (7) と Rayleigh-Ritz 法を用いて座屈解を求める と, 次の座屈モーメントが得られる.

$$
\begin{aligned}
M_{c r}{ }^{2}= & \frac{\pi^{2} E I_{y}}{L^{2}}\left(G K_{T}+\frac{\pi^{2} E I_{\omega}}{L^{2}}\right)+\frac{\pi^{2} E I_{y}}{L^{2}} \\
& \cdot \frac{2 K_{x} L}{\pi^{2}} \cdot \frac{81 \frac{\pi^{2} E I_{\omega}}{L^{2}}+9 G K_{T}}{81 \frac{\pi^{2} E I_{\omega}}{L^{2}}+9 G K_{T}+\frac{2 K_{x} L}{\pi^{2}}} \\
& \doteqdot \frac{\pi^{2} E I_{y}}{L^{2}}\left(G K_{T}+\frac{\pi^{2} E I_{\omega}}{L^{2}}\right)+\frac{\pi^{2} E I_{y}}{L^{2}} \cdot \frac{2 K_{x} L}{\pi^{2}}
\end{aligned}
$$

式（8）で示される座屈モーメントと 2 次の座屈モー メント

$$
M_{c r}{ }^{2}=\frac{4 \pi^{2} E I_{y}}{L^{2}}\left(G K_{T}+\frac{4 \pi^{2} E I_{\omega}}{L^{2}}\right)
$$

が等しくなる $K_{x}$ を基準ねじれ拘束ばね定数 $K_{1}$ と定 義する. すなわち,

$$
\begin{aligned}
K_{1} & =\frac{1.5}{L}\left(G K_{T}+5 \frac{\pi^{2} E I_{\omega}}{L^{2}}\right) \\
& \doteqdot 3.7 E W_{F}\left(\frac{d}{L}\right)^{2}\left(\frac{b}{L}\right)\{0.1 \kappa+5\}
\end{aligned}
$$

である.ここに, $W_{F}$ : 圧縮フランジのフランジ面内に関 する弾性断面係数, $\kappa$ : ねじり定数比 $\kappa=L \sqrt{G K_{T} / E I_{\omega}}$ である。

図一11 の上段は $\bar{\lambda}=3.0$ なる 並列桁が横桁 2 本有す る場合の曲げモーメント図と座屈モードを示し，下段 は，上段の横桁によって拘束される曲げモーメントの最 も大きい拘束点間を単純ばりと仮定した場合の座屈モー ドを示す. ねじれ拘束ばね定数 $\left(K_{x}=30 K_{1}\right)$ のみ有す る横桁 2 本を等間隔に配置した場合，拘束点でねじれは ほぼ完全に拘束されているが，横変位は拘束されていな い.しかしながら，並列主桁の方が下段に示す桁要素に

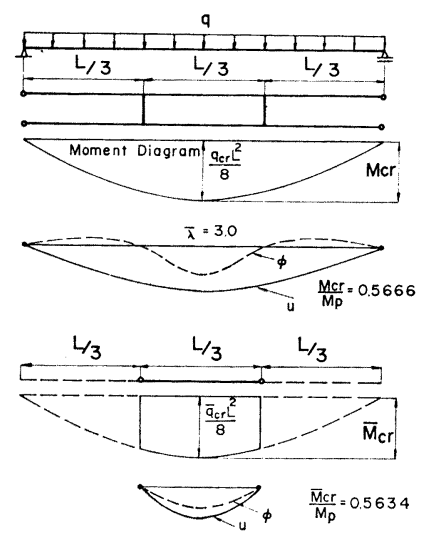

Fig. 11 Definition of the Standard Critical Moments

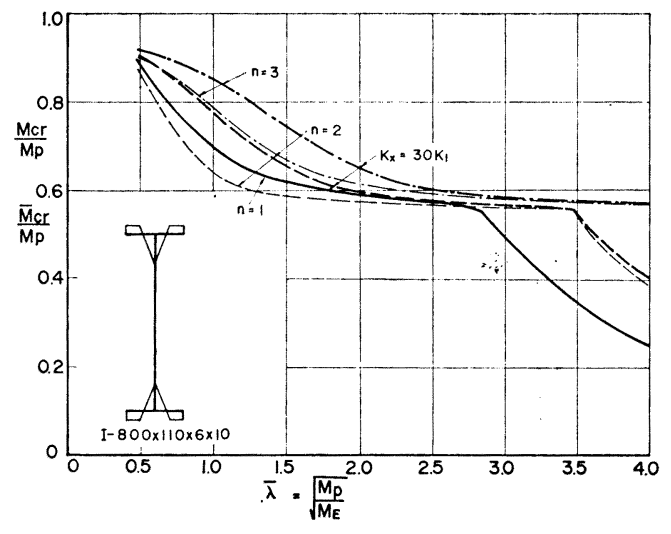

Fig. 12 Relationship Between Lateral Buckling Curves of Parallel Beams and Equivalent Beam Segments

対する座屈強度よりわずかに大きい座屈強度を示すのみ である。

ここに，桁要素に対する座屈強度とは Fig. 11 の下 段に示すように, 最も曲げモーメントの大きい拘束点間 を単純ばりと仮定し, 並列桁と同一のモーメントが作用 する場合の座屈強度を指しており，これを基準座屈モー メント $\bar{M}_{c r}$ と定義する.

Fig. 12 は横桁 $(n=1,2,3), K_{x}=30 K_{1}$, を有する 並列析の座屈モーメント $M_{c r}$ と基準座屈 モーメント $\bar{M}_{c r}$ の関係を示す. 図中, 太線は並列桁を, 細線は桁 要素を示し, 実線は横桁 1 本の場合を, 点線は 2 本の場 合を, 一点鎖線は 3 本の場合を示す. 横桁 1 本の場合, 両者は同一強度を示し, 横析 2 本および 3 本の場合は隣 接スパンの影響により, 並列桁の方が析要素より常に大 きな座屈強度を示す.

次に, 並列桁の座屈強度を $\bar{M}_{c r}$ より大きくするに必 要なねじれ拘束ばね定数 $K_{x}$ の検討を行う.

Fig. 13 は $\bar{\lambda}=3.0$, および $\bar{\lambda}=1.0$ の場合の並列桁 の座屈強度とねじれ拘束ばね定数との関係を, 横析本数 をパラメーターとして示してある. 縦軸は $M_{c r}$ と基準 座屈モーメント $\bar{M}_{c r}$ の比をとり，横軸には $K_{x}$ と基 準ねじれ拘束ばね定数 $K_{1}$ の比をとっている. なお， 図中の表は各横析本数に対する基準座屈モーメント值を 示す. 図より, $\bar{\lambda}=3.0$ の場合， $\bar{M}_{c r}$ を維持するに必要 なねじれ拘束ばね定数の值は横析本数によって多少異な る. $\bar{\lambda}=1.0$ の場合, 並列桁は非弹性座屈し, $\bar{M}_{c r}$ を維 持するに必要な $K_{x}$ の值は主桁断面剛性の低下により 約 $0.2 K_{1}$ 程度となる.

Fig. 14 および 15 は直線タイプおよび放物線タイプ の残留応力を有する比較的細長い並列桁 ( $\bar{\lambda}=3.0)$ の座 屈強度とねじれ拘束ばね定数の関係を示す. また, 図中 の表は各断面および横桁本数に対する基準座屈モーメン 


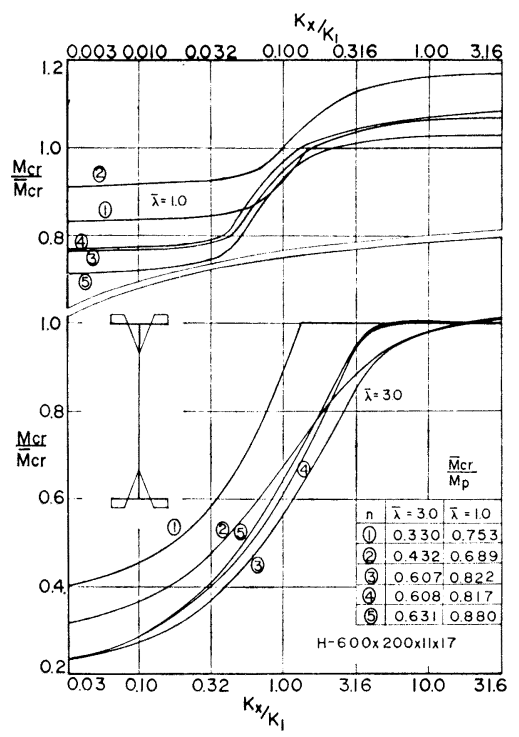

Fig. 13 Effect of Number of Cross Beams on the Lateral Buckling Strength

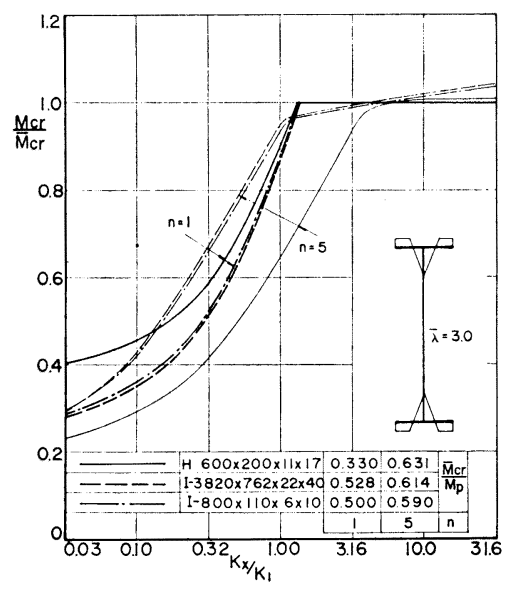

Fig. 14 Effect of $K_{x}$ on the Buckling Strength (Linear Residual Stress Distribution)

トの值を示す. 図より, 弾性座屈する $n=1$ の場合, 残 留応力分布形状の違いによる影響はほとんどなく,はり タイプに近い H-600×200×11×17 mm の断面を除け ば断面形状の影響も小さい.

Fig. 16 は比較的ずんぐりした並列桁（ $\bar{\lambda}=1.0 ）$ の横 倒れ座屈強度と, ねじれ拘束ばね定数の関係を示してい る. 図の上段は, 放物線タイプの残留応力を有する場合 を, 下段は直線タイプの残留応力を有する場合を示す. $\bar{\lambda}=1.0$ の場合, 断面形状および残留応力分布形状の影 響はほとんどみられない。

Fig. 13〜16 において, 並列桁の座屈モーメント $M_{c r}$ を基準座屈モーメント $\bar{M}_{c r}$ で無次元表示し, 㸚じれ拘 束ばね定数 $K_{\alpha}$ を基準ねじれ拘束ば㱛定数 $K_{1}$ で無次

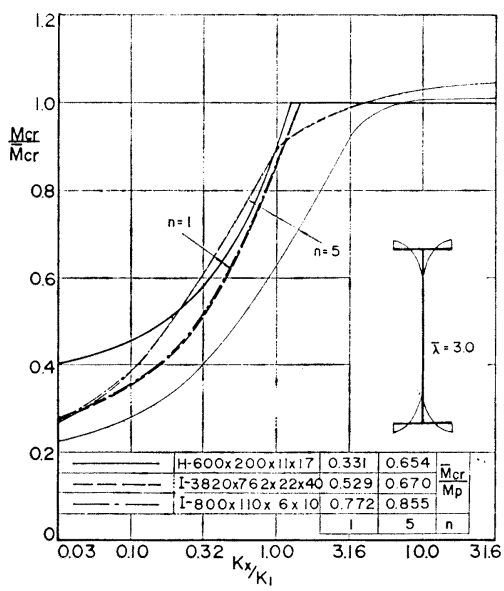

Fig. 15 Effect of $K_{x}$ on the Buckling Strength (Parabolical Residual Stress Distribution)

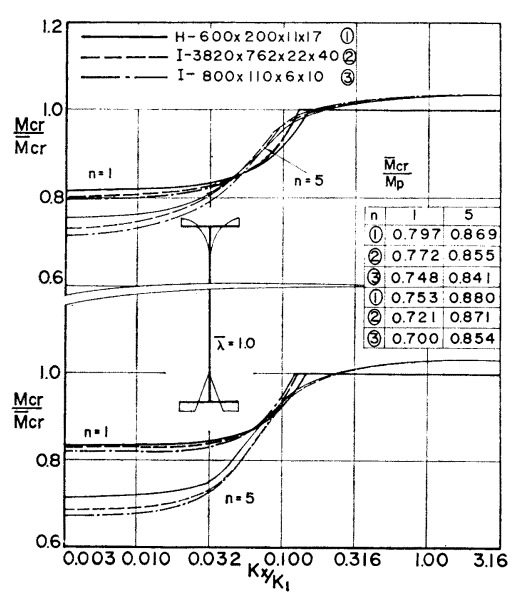

Fig. 16 Effect of $K_{x}$ on the Buckling Strength $(\bar{\lambda}=1.0)$

元表示した.また，Fig. 14 16 の表から， $n=1$ およ び 5 の場合の $M_{c r}$ 值を $\bar{M}_{c r}, M_{p}$ を用いて求めるこ とができる.なお，このような表示方法によれば断面形 状, 残留応力分布形状, および横桁本数の $M_{c r} / \bar{M}_{c r}$ に 及ぼす影響は小さくなり, $M_{c r} / \bar{M}_{c r}=1$ を確保するた めの横桁の必要対じれ拘束ばね定数は容易に求めること ができる.

Fig. 17 および 18 は直線タイプおよび放物線タイプ の残留応力分布を有する 3 種の並列桁の座屈強度曲線を $M_{c r} / M_{p}-\bar{\lambda}$ 座標に示す. 図中, 下段の曲線は横桁がな い場合を, 中段の曲線は横桁 1 本, 上段の曲線は横析 5 本有する場合を示す. 図より並列析が弾性座屈する場 合, 座屈強度は横析本数によって大きく異なり, 非弹性 座屈する場合, 横桁本数による強度増加 は小さく, ま た，断面形状による強度差も小さいことがわかる.

Fig. 19 は横桁を並列析のスパン中央に対して対称に 


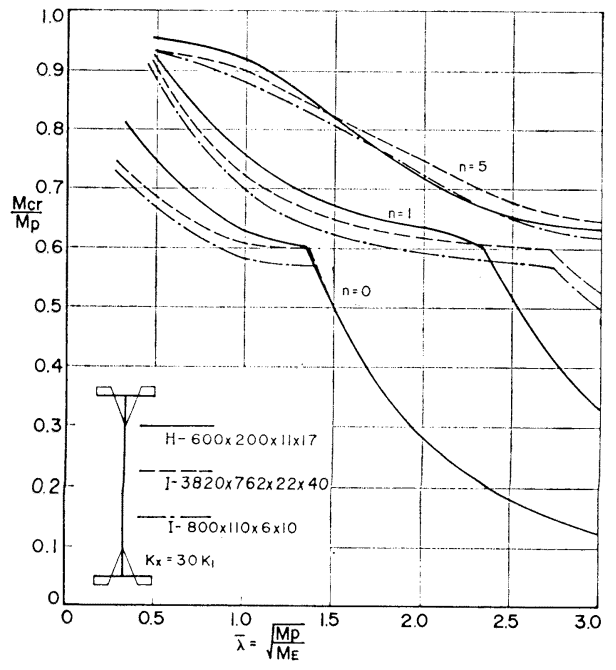

Fig. 17 Lateral Buckling Curves (Linear Residual Stress Distribution)

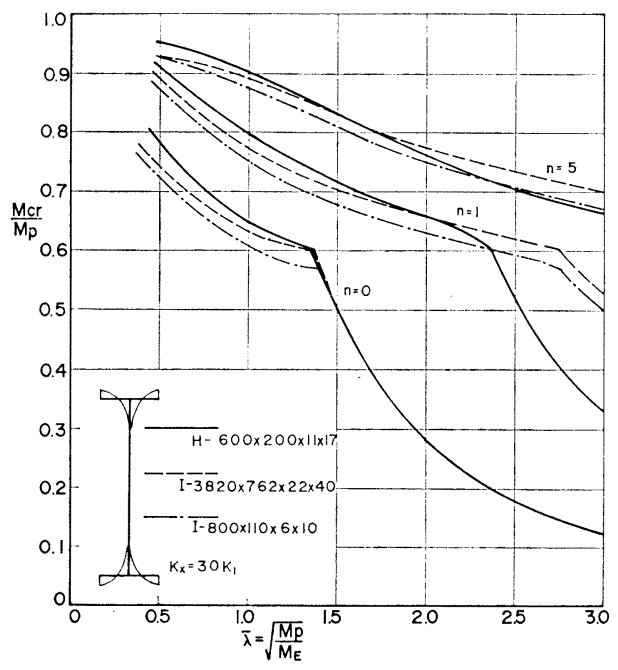

Fig. 18 Lateral Buckling Curves (Parabolical Residual Stress Distribution)

3 本および 5 本配置した場合の横析位置と座屈強度の関 係を示している. 横軸は桁中間の横桁位置を示し, 図中 の $\lambda_{1}$ は桁端に近い方の横桁位置を示す. $n=3$ (太線) では, 横桁位置が桁端より中央に移動するにつれて座屈 強度は大きく増大し, 座屈強度が弾性限界（約 $\lambda_{2}=0.25$ の位置）を越えると並列析の断面剛性の低下により強度 増加は少なくなり, 横桁位置が約 $0.37 L$ を越えると座 屈強度は急激に減少する. 細い曲線群は横桁 5 本有し, 桁端に近い方の横桁を黒丸印の位置に固定し, 桁中間の 横桁位置を変化させた場合の座屈強度の変化を表わして いる. $n=5$ では, 桁端より約 $0.30 \mathrm{~L}$ の位置と約 0.43 $L$ の位置 および桁中央に横桁 5 本配置すれば座屈強度 は最も大きくなる. 図より, 座屈に対して横桁を効果的

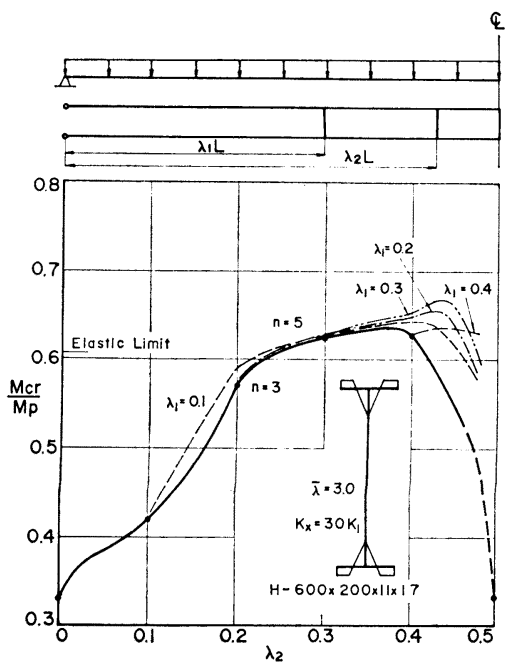

Fig. 19 Effect of the Locations of Cross Beams on the Lateral Buckling

に配置するには，等間隔よりやや桁中央よりに配置すれ ばよいことがわかる。

\section{4. 結 論}

本研究は横桁のもつ各種剛度が並列主桁に対してもつ 横補剛効果の検討を行い, 桁の圧縮フランジの曲げ応力 の照査に用いられる固定点間距離の概念について検討を 加えたものである. そして，並列桁全体として設計抵抗 モーメントを安全に維持するための補剛条件を満足させ るに必要な横桁の必要剛度と並列主桁を補剛する位置に ついても検討を行った.

本研究により，次のことが明らかになった。

（1）横析の並列主桁に対する横補剛効果としては, 主析のねじれを拘束する横桁の強軸まわりの断面 2 次モ 一メントの影響が最も大きい. 両主桁の横変位差を拘束 する横桁断面積はきわめて小さな值（主桁圧縮フランジ 面積の $10^{-4}$ 倍) で十分である. 横桁による横補剛効果 は, 同一の横桁剛度に対して各載荷状態とも, ほぼ一様 な強度の上昇をみることができる。

（2）拘束点間を単純ばりとみなした 基準座屈強度 $\bar{M}_{c r}$ と式（9）で表わされる基準ねじれ拘束ばね定数 $K_{1}$ をパラメーターとして，横桁を有する並列主桁の座 屈強度を表現すると Fig. 14 および 15 より明らかな ように, 断面形状および残留応力分布形状の座屈強度に 及ぼす影響は表われなくなる.

横桁によるねじれ拘束ばね定数 $K_{x}$ は Fig. 13 から も明らかなように各横桁本数により $K_{1}$ の 1 12 倍程 度の剛度を確保しておけば，拘束点がいわゆる固定点 としての機能を満足し，この場合は設計上よく用いられ 
る固定点間を単純ばりとみなした基準座屈強度よりも常 に大きな座屈值を示している.

（3）通常の構造寸法を有する並列栴は桁中央の横桁 1 本で大きな横補剛効果を期待できる. 座屈に対して横 桁在上り効果的に配置する方法は，Fig. 19 からも明ら かなように等間隔上り，むしろ並列桁中央をより密にす ればよい。

本研究の数值尌算にあたっては, 金沢工業大学計算機 センターの IBM 370-158を用いた。

「記号「

$b$ : Flange width of I-section

$d$ : Depth of I-section

$E$ : Young's modulus of elasticity

$K_{A}$ : Spring constant for axial rigidity

$K_{x}, K_{y}$ : Spring constants for flexural rigidity about the $x$ - and $y$-axes, respectively

$K_{1}$ : Standard spring constant defined by Eq. 9

$L$ : Length of parallel beams

$L_{c}$ : Length of cross beam specified by $L_{c}=$ $40 r_{y}$

$M_{c r}$ : Critical moment defined by $M_{c r}=q_{c r} L^{2}$ 8

$\bar{M}_{c r}$ : Standard critical moment defined in Fig. 11

$M_{E}$ : Elastic lateral buckling moment of simple supported beam

$M_{p}, M_{y}:$ Full plastic moment and yield moment, respectively

$n:$ Number of cross beams

$P_{y}$ : Concentrated yield load given by $P_{y}=$ $4 M_{y} / L$

$q_{y}$ : Uniform distributed yield load given by $q_{y}=8 M_{y} / L^{2}$

$t:$ Flange thickness of I-section

$w:$ Web thickness of I-section

$\alpha$ : Ratio of buckling load to yield load

$\delta$ : Ratio of area of cross beam to flange area of I-section

$\bar{\lambda}$ : Modified length defined by $\bar{\lambda}=\sqrt{M_{p} / M_{E}}$

$\sigma_{r c}, \sigma_{r t}$ : Magnitudes of compressive and tensile residual stress

$\sigma_{y}:$ Yield stress

\section{参 考 文 献}

1）鈴木敏郎・小野徹郎：塑性設計梁に関する実験的研究 1 $\sim 3$, 建築学会論文報告集, 第 $168,171,175$ 号, 昭和 45 年 2 月, 5 月, 9 月.

2) 鈴木敏郎・小野徹郎：塑性設計梁の補剛材岡性について, 建築学会論文報告集, 第 202 号, 昭和 47 年 12 月.

3）鈴木敏郎・小野徹郎：高張力梁の塑性設計に関する研究, 建築学会論文報告集, 第 219 号, 昭和 49 年 5 月.

4) Lee, G.C. and Galambos, T.V. : Post-Buckling Strength of Wide-Flange Beams, Proc. of ASCE, Vol. 88, No. EM 1, Feb., 1962.

5) Lay, M.G. and Galambos, T.V. : Inelastic Beams under Moment Gradient, Proc. of ASCE, Vol. 93, No. ST 1, Feb., 1967.

6) 最相元雄 - 田中尚: H 形鋼梁の横補剛に関寸る研究, その 1 ，その 2 , 建築学会論文報告集, 第 223,224 号, 昭和 49 年 9 月, 10 月.

7) Zuk, W. : Lateral Bracing Forces on Beams and Columns, Proc. of ASCE, Vol. 82, No. EM 3, July, 1956.

8) Schmidt, L.C. : Restraints Against Elastic Lateral Buckling, Proc. of ASCE, Vol. 91, No. EM 6, Dec., 1965.

9) Massey, C. : Lateral Bracing Force of Steel I Beams, Proc. of ASCE, Vol. 88, No. EM 6, Dec., 1962.

10) Lay, M.G. and Galambos, T.V.: Bracing Requirments for Inelastic Beams, Proc. of ASCE, Vol. 92, No. ST 2, April, 1966.

11) Hartmann, A.J. : Elastic Lateral Buckling of Continuous Beams, Proc. of ASCE, Vol. 93, No. ST 4, Aug., 1967.

12) Pincus, G. and Fisher, G.P. : Behavior of DiaphragmBraced Columns and Beams, Proc. of ASCE, Vol. 92, No. ST 2, April, 1966.

13) Errera, S.J., Pincus, G. and Fisher, G.P. : Columns and Beams Braced by Diaphragms, Proc. of ASCE, Vol. 93, No. ST 1, Feb., 1967.

14) Taylor, A.C. and Ojalvo, M. : Torsional Restraint of Lateral Buckling, Proc. of ASCE, Vol. 92, No.ST 2, April, 1966.

15）福本唀士 - 久保全弘：横倒れ座屈強度と横補剛勃果, JSSC, Vol. 7, No. 71, 昭和 46 年 11 月.

16）福本唀士・久保全弘：横補剛されたはりの横倒れ座屈に 関する研究, 建築学会論文報告集, 第 206 号, 昭和 48 年 4 月.

17）吉田 博・井本芳宏：拘束をうけるはりの弾性および非 弾性横倒れ座屈解析, 土木学会論文報告集, 第 208 号, 1972 年 12 月.

18) Unger, B. : Elastisches Kippen von beliebig gelagerten und aufgehängten Durchlaufträgern mit einfachsymmetrischem, in Trägerachse veränderlichem Querschnitt und einer Abwandlung des Reduktionsverfahrens als Lösungsmethode, Dissertation, Technischen Hochschule Darmstadt, 1969.

19）福本唀士・藤原 稔 - 渡辺信夫 : 溶接 I 形部材の横倒れ 座屈に関する実験的研究, 土木学会論文報告集, 第 189 号, 1971 年 5 月.

(1977.4.4 · 受付) 